\section{Response to: 'Comment on: standardisation of myositis-specific antibodies: where are we today?' by Infantino et al}

We agree with the notions made by Infantino et $a l^{1}$ in their reply to our previously published report ${ }^{2}$ concerning the need for multicentre studies to obtain large enough number to validate new methods for detection of myositis-specific antibodies (MSA) and myositis-associated autoantibodies (MAA). We also agree with the suggestion to evaluate the possibility to individualise reference ranges (cut-off values) for the individual autoantibodies in multi-autoantibody assays like line immune assays (LIA). In relation to such proposals, we would like to stress our experience that the same LIA might yield very quantitatively divergent results in different laboratories, for example, due to differences in laboratory temperature ${ }^{3}$ but certainly also other factors, and that these quantitative differences may result in qualitatively divergent results. One way to help standardisation of laboratory results might be to include quantitative internal controls for the individual autoantibodies included in the LIAs, as we have discussed before. ${ }^{4}$ Multicentre studies on the evaluation of LIAs or other methods for detection of MSA and MAA should preferably be combined with use of such common internal controls in the participating laboratories.

Johan Rönnelid $\odot$, ' Fabricio Espinosa-Ortega $\odot,{ }^{2}$ Ingrid E Lundberg $\odot^{2,3}$ ${ }^{1}$ Department Immunology, Genetics and Pathology, Uppsala University, Uppsala, Sweden

${ }^{2}$ Medicine, Division of Rheumatology, Karolinska Institutet, Karolinska University Hospital, Stockholm, Sweden

${ }^{3}$ Center for Molecular Medicine, Karolinska Institutet, Stockholm, Sweden

Correspondence to Professor Ingrid E Lundberg, Medicine, Division of Rheumatology, Karolinska Institutet, Karolinska Univeristy Hospital, Stockholm SE171 76, Sweden; ingrid.lundberg@ki.se

Handling editor Josef S Smolen

Twitter Fabricio Espinosa-Ortega @fabstag
Contributors All authors have equally contributed.

Funding The authors have not declared a specific grant for this research from any funding agency in the public, commercial or not-for-profit sectors.

Competing interests None declared.

Patient consent for publication Not required.

Provenance and peer review Commissioned; internally peer reviewed.

(c) Author(s) (or their employer(s)) 2021. No commercial re-use. See rights and permissions. Published by BMJ.

\section{Check for updates}

To cite Rönnelid J, Espinosa-Ortega F, Lundberg IE. Ann Rheum Dis 2021;80:e116.

Received 2 October 2019

Accepted 2 October 2019

Published Online First 15 October 2019

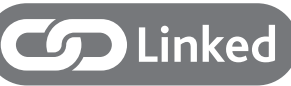

http://dx.doi.org/10.1136/annrheumdis-2019-216217

Ann Rheum Dis 2021;80:e116. doi:10.1136/annrheumdis-2019-216248

\section{ORCID iDs}

Johan Rönnelid http://orcid.org/0000-0003-1186-3226

Fabricio Espinosa-Ortega http://orcid.org/0000-0001-6227-8209

Ingrid E Lundberg http://orcid.org/0000-0002-6068-9212

\section{REFERENCES}

1 Infantino M, Manfredi M, Bizzarro N. Comment on: standardisation of myositis-specific antibodies: where are we today? Ann Rheum Dis 2021;80:e115.

2 Espinosa-Ortega F, Holmqvist M, Alexanderson $\mathrm{H}$, et al. Comparison of autoantibody specificities tested by a line blot assay and immunoprecipitation-based algorithm in patients with idiopathic inflammatory myopathies. Ann Rheum Dis 2019;78:858-60.

3 Rönnelid J, Barbasso Helmers S, Storfors H, et al. Use of a commercial line blot assay as a screening test for autoantibodies in inflammatory myopathies. Autoimmun Rev 2009;9:58-61.

4 Rönnelid J, Espinosa-Ortega F, Lundberg IE. Response to: 'Semi-quantitative analysis of line blot assay for myositis-specific and myositis-associated antibodies: a better performance?' by Cavazzana et al. Ann Rheum Dis 2020;79:e153. 